\title{
Strength and Performance of Straw Ash Cement Mortar
}

\author{
Fucheng Wang ${ }^{1 *}$, Chun Wang ${ }^{1,2}$, Shujuan $\mathrm{Yi}^{1}$ \\ ${ }^{1}$ Heilongjiang Bayi Agricultural University Engineering College, Daqing 163319, China \\ ${ }^{2}$ Chinese Academy of Tropical Agricultural Science, Zhanjiang 524000, China
}

Corresponding Author Email: wangchun1963@126.com

https://doi.org/10.18280/rcma.290103

Received: 16 November 2018

Accepted: 9 January 2019

\author{
Keywords: \\ rice straw ash, cement mortar, water \\ absorption, compressive strength, flexural \\ strength
}

\begin{abstract}
This paper mainly explores the strength and performance of rice straw ash cement mortar. Firstly, the straw ash was obtained through high-temperature calcination, and the ash formation rate was measured. Then, the straw ash was rinsed with clean water and mixed into cement mortar test pieces. According to the mass ratio of cement in the test pieces, the proportion of straw ash were determined as $5 \%, 10 \%, 15 \%$ and $20 \%$, respectively. Next, the following properties of each test piece were measured, including water absorption rate, $3 \mathrm{~d}$ and $28 \mathrm{~d}$ flexural strength and compressive strength. On this basis, the flexural strength and compressive strength were fitted and correlated with the proportion of straw ash. The fitting formulas and correlation functions proposed in this paper lay a theoretical basis for the engineering application of straw ash cement mortar.
\end{abstract}

\section{INTRODUCTION}

Straw ash cement mortar is a kind of biomass ash with the characteristics of volcanic ash activity, recyclable, and environmental-friendly; it is produced by treating rice straw with high-temperature calcination, and can be used to replace cement to prepare green building materials. The research and application of straw ash cement mortar is of great prospect since China is a big agricultural country, and our country has a huge rice yield every year; a large amount of rice straw is being produced every year, and there're a large amount of residual straw resources, most of which have not been utilized. At present, especially in large-area rice planting areas, the treatment of rice straw is facing problems. The common treatment method is burning the straw on the spot, which not only causes air pollution, but also results in a waste of straw resources and even fire disaster. In recent years, the government has conducted policy surveillance on rice straw burning, but how to effectively treat rice straw is still a challenge for the agriculture industry [1]. If the straw could be effectively utilized, it can be turned from a waste into a treasure. The straw can be produced into straw ash with volcanic ash properties, and it can be used to replace the cement content in the cement mortar for the construction of city and farmland. On the other hand, with the acceleration of urbanization and the improvement of the standardization level of the farmland industry, the production and consumption of cement have further increased, which has consumed a large amount of energy and resources; in such context, using rice straw to partially replace cement is of important strategic significance, which not only saves resources, but also protects the environment, and it's in line with the idea of green and sustainable development of contemporary construction industry.

In recent years, experts and scholars at home and abroad have carried out a series of researches on the performance of straw ash cement mortar, and have obtained certain research results. Birick et al. found through research that plants can accumulate amorphous silicon in soil into plant straw by their own action in the form of biomineralization, which determines the feasibility of straw ash application [2]; Le yuan et al. studied the burning characteristics of straw and found that the $\mathrm{SiO}_{2}$ content in straw biomass ash was higher [3]; Zhang Qiang et al. prepared the straw ash concrete test pieces and analyzed its influence on the tensile properties of concrete. When the admixture proportion was $5 \%$, the performances of straw ash concrete and the standard test pieces were almost the same [4-5]; Ouyang Dong prepared rice hull ash by lowtemperature incineration and found its biomass ash contains a large number of Nano-scale $\mathrm{SiO}_{2}$ particles and pores, he analyzed the reason for its high volcanic ash activity, and found that the addition of a certain amount of rice hull ash into the concrete has a significant enhancement effect on the mechanical properties [6]; in order to further find the internal relationship between the flexural strength, the compressive strength of rice straw ash cement mortar and the proportion of straw ash, this paper selects rice straw to prepare the straw ash, and explores the influence of different proportions of rice straw ash on the flexural and compressive properties of cement mortar test pieces, then it proposes fitting calculation formulas and verifies the rationality of the fitting formulas through experimental data.

\section{MATERIALS AND METHODS}

\subsection{Materials}

Rice straw: the experimental rice straw was from a rice breeding experiment field of the agricultural college of Heilongjiang Bayi Agricultural University. After the rice straw was harvested, the impurities in the rice straw were removed, and the rice straw was dried naturally and calcined in a muffle furnace at $500{ }^{\circ} \mathrm{C}$ for $6 \mathrm{~h}$,and then the ash samples 
were taken out, and the hard straw ash chunks contained in the original ash samples were ground by a ball mill to ensure the uniformity of the particle size of the straw ash.

Cement: P.O32.5 grade Portland cement, the Youlong
(Brand) cement produced in Daqing City, Heilongjiang Province, the production date is 15 days before mixing. The composition of the cement is shown in Table 1 below:

Table 1. Chemical composition of the cement

\begin{tabular}{ccccccccccc}
\hline Chemical composition & $\mathrm{SiO}_{2}$ & $\mathrm{Al}_{2} \mathrm{O}_{3}$ & $\mathrm{Fe}_{2} \mathrm{O}_{3}$ & $\mathrm{CaO}$ & $\mathrm{MgO}$ & $\mathrm{SO}_{3}$ & $\mathrm{Na}_{2} \mathrm{O}$ & $\mathrm{f}-\mathrm{CaO}$ & Loss on calcination & $\mathrm{Cl}-$ \\
Percentage \% & 20.96 & 4.85 & 3.53 & 63.26 & 2.80 & 2.51 & 0.57 & 0.89 & 1.40 & 0.011 \\
\hline
\end{tabular}

Sand: standard sand, produced by Xiamen Sinoma Co., Ltd., the quality standard sand grading met the requirements, grading region for coarse sand: 3.7 3.1; grading region for medium sand: 3.0 2.3; grading region for fine sand: 2.2 1.6.

\subsection{Experimental methods}

This study took the straw ash proportion as the influencing factor to conduct experiment and studied its influence on the compressive and flexural strength of straw ash cement mortar. The experiment determined that the water-binder ratio was 0.5 and the sand ratio was 0.3 . The proportion of straw ash was designed to be $0 \%, 5 \%, 10 \%, 15 \%$ and $20 \%$ of the mass of straw ash cement mortar, then the cement mortar test pieces were prepared and subject to the compressive and flexural properties experiment. A $40 \mathrm{~mm} \times 40 \mathrm{~mm} \times 160 \mathrm{~mm}$ rectangular steel standard mold was used to fabricate the cement mortar test pieces, and 12 test pieces were fabricated for each proportion. A cement paste mixer was adopted for the cement mortar stirring experiment, and the full-auto mode was used for stirring. Water immersion curing under NPT (normal pressure and temperature) was adopted and the curing temperature was around $23{ }^{\circ} \mathrm{C}$. The test pieces were cured for $3 \mathrm{~d}$ before early flexural strength and compressive strength tests, and were cured for $28 \mathrm{~d}$ before the final flexural strength and compressive strength tests, and the arithmetic mean of the test pieces was taken as the experimental result. A flexural and compressive strength test machine produced by Shanghai Sansi Tech. was adopted for measuring the flexural and compressive strength of the cement mortar. The design of the sand-binder ratio was based on the Regulations for Mix Proportion Design of Ordinary Concrete (JGJ55-2011) [7], and the flexural and compressive strength tests were carried out according to the Standard for Test Method of Mechanical Properties on Ordinary Concrete (GB/T 50081-2002) [8], the ratios of the straw ash cement mortar are shown in Table 2.

Table 2. Mixing ratio of straw ash cement mortar

\begin{tabular}{cccccc}
\hline No. & Straw ash mass fraction \% & Water-binder ratio & Cement $(\mathrm{g})$ & Water $(\mathrm{ml})$ & Sand $(\mathrm{g})$ \\
1 & 0 & 0.5 & 150 & 75 & 450 \\
2 & 5 & 0.5 & 142.5 & 75 & 450 \\
3 & 10 & 0.5 & 135 & 75 & 450 \\
4 & 15 & 0.5 & 127.5 & 75 & 450 \\
5 & 20 & 0.5 & 120 & 75 & 450 \\
\hline
\end{tabular}

\subsection{Model error analysis}

SSE, correlation coefficient, coefficient of determination, and RMSE were adopted to analyze the calculation accuracy of the model.

$$
\begin{aligned}
& \operatorname{SSE}=\sum_{j=1}^{i}\left(Y_{j}-X_{j}\right)^{2}, \text { R-square }=\frac{S S R}{S S T}, \operatorname{SSR}=\sum_{j=1}^{i}\left(Y_{j}-\bar{X}_{j}\right)^{2}, \\
& \operatorname{SST}=\sum_{j=1}^{i}\left(X_{j}-\bar{X}_{j}\right)^{2}, \text { RMSE }=\sqrt{\frac{1}{m} \sum_{j=1}^{i}\left(Y_{j}-X_{j}\right)^{2}} .
\end{aligned}
$$

where, $Y_{j}$ represents the fitting formula value, $X_{j}$ represents the original experimental data, $\bar{X}_{j}$ represents the mean of the original experimental data, the coefficient of determination is mostly used for complex models. Since the proposed model is a simple linear model, the coefficient of determination is equivalent to the square of the correlation coefficient, to verify the fitting accuracy of the fitting formula for the model, the coefficient of determination is calculated.

\section{RESULTS AND ANALYSIS}

\subsection{Straw ash formation rate}

After harvested, the rice straw had been washed for more than three times to remove impurities attached to it to ensure the accuracy of the experimental results [9, 21], and then dried outside the room under the natural condition for later use; after that, the rice straw was calcined in a muffle furnace at $500{ }^{\circ} \mathrm{C}$, $600{ }^{\circ} \mathrm{C}$, and $815^{\circ} \mathrm{C}$ for $4 \mathrm{~h}$, and the ash formation rates were measured, the results are shown in the following table.

Table 3. Ash formation rate of rice straw

\begin{tabular}{ccc}
\hline $\begin{array}{c}\text { Calcination method } \\
\left({ }^{\circ} \mathrm{C}\right)\end{array}$ & $\begin{array}{c}\text { Calcination time } \\
(\mathrm{h})\end{array}$ & $\begin{array}{c}\text { Ash formation rate } \\
(\%)\end{array}$ \\
500 & 2 & 13.82 \\
500 & 4 & 11.03 \\
600 & 2 & 11.87 \\
600 & 4 & 10.97 \\
815 & 2 & 10.86 \\
815 & 4 & 9.71 \\
\hline
\end{tabular}

It can be seen from Table 3 that, no matter calcined at $500{ }^{\circ} \mathrm{C}$ or $815^{\circ} \mathrm{C}$, under the same calcination temperature, the ash formation rate of the rice straw decreased with the increase of the calcination time, indicating that at the same calcination temperature, the longer the calcination time, the burning of the biomass is more sufficient, and many inorganic elements that are existing in the form of organic matter are more volatile, resulting in a lower ash formation rate; When the calcination time was the same, the ash formation rate decreased with the increase of the calcination temperature, indicating that the burning of the biomass is not sufficient, even long calcination 
time couldn't make the burning of the flammable components completely sufficient. In this paper, straw ash that was calcined at $500{ }^{\circ} \mathrm{C}$ for $4 \mathrm{~h}$ was taken as the experimental material. The straw was calcination and finally ashed as shown in the Figure 1 and Figure 2.

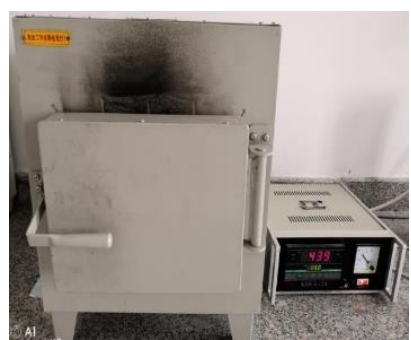

Figure 1. Muffle furnace calcination at $500^{\circ} \mathrm{C}$

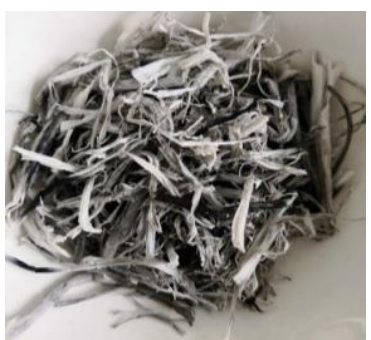

Figure 2. Straw ash that was calcined at $500{ }^{\circ} \mathrm{C}$

\subsection{Test piece water absorption rate}

After 28 days of curing, the test pieces of rice straw ash cement mortar were subject to the water absorption rate test. First, after dried $4 \mathrm{~h}$ at $75{ }^{\circ} \mathrm{C}$ in an electric heating constant temperature air dry oven, the mass of the test pieces was measured. Second, the test pieces were immersed in clean water for $48 \mathrm{~h}$, after the residual water on the surface of the test pieces had been removed, their mass [10-12] was measured again for comparison, and the obtained test piece water absorption rates are shown in Table 4.

Table 4. Water absorption rate of test pieces

\begin{tabular}{ccc}
\hline Straw ash & Mean mass & Water absorption \\
proportion $(\%)$ & difference $(\mathrm{g})$ & rate $(\%)$ \\
0 & 9.953 & 1.766 \\
5 & 11.843 & 2.081 \\
10 & 11.877 & 2.140 \\
15 & 12.161 & 2.141 \\
20 & 16.001 & 2.942 \\
\hline
\end{tabular}

It can be seen from Table 4 that with the gradual increase of rice straw ash proportion, the water absorption rate of straw ash cement mortar test pieces gradually increased. When the straw ash proportion was between $5 \%-15 \%$, the water absorption rate did not change much. When the straw ash dosage was $20 \%$, the water absorption rate increased obviously. The above data show that, in the cement mortar, when the cement is replaced by rice straw ash of the same amount, the water absorption rate would increase, and when the proportion of straw ash increases from zero to $5 \%$, the water absorption rate has increased by $17.84 \%$, indicating that the cement mortar test pieces have a stronger water absorption capacity, but the increment of water absorption is relatively slow when the proportion of straw ash is between $5 \%-15 \%$, and when the proportion of straw ash reaches $20 \%$, the increment of water absorption is relatively obvious, this is because with the increase of the proportion of straw ash in the cement mortar, the test pieces have more pores, resulting in increase in the water absorption rate.

The test pieces ware dried as shown in the Figure 3 and Figure 4. Change law of test piece water absorption rate of rice straw ash cement mortar was described as shown in the figure 5 .

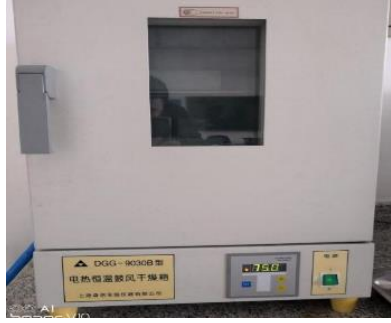

Figure 3. Electric heating constant temperature air dry oven

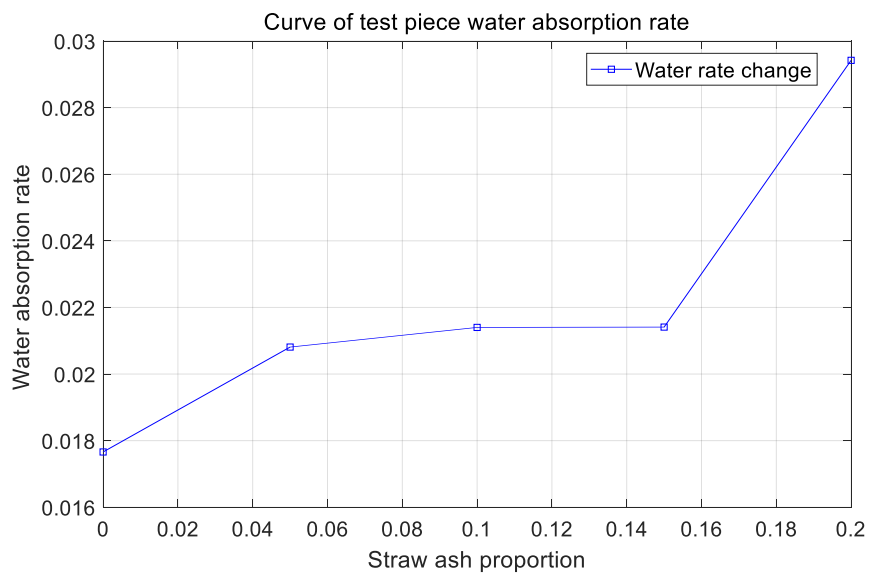

Figure 5. Change law of test piece water absorption rate of rice straw ash cement mortar

\subsection{Strength of cement mortar}

Cement mortar flexural strength and compressive strength

The test results of the flexural and compressive strength of the rice straw ash cement mortar are shown in Table 5.

In terms of the damage pattern of straw ash cement mortar test pieces, it can be seen from Figure 7 that, the flexural damage of the test piece was dominated by breakage. In the experiment process, when the test machine was loaded to the critical point, the test piece appeared tiny cracks, when the loading exceeded a certain time limit, as the external load value increased slowly, the test piece rattled and completely lost its bearing capacity. The flexural damage of the test piece was mainly the crack penetration and caused damages [13-16].

Table 5. Test data of mechanical properties of test pieces

\begin{tabular}{ccccc}
\hline $\begin{array}{c}\text { Rice straw ash } \\
\text { proportion \% }\end{array}$ & $\begin{array}{c}\text { Flexural strength (3d) } \\
\mathrm{N} / \mathrm{mm}^{2}\end{array}$ & $\begin{array}{c}\text { Flexural strength (28d) } \\
\mathrm{N} / \mathrm{mm}^{2}\end{array}$ & $\begin{array}{c}\text { Compressive strength (3d) } \\
\mathrm{N} / \mathrm{mm}^{2}\end{array}$ & $\begin{array}{c}\text { Compressive strength (28d) } \\
\mathrm{N} / \mathrm{mm}^{2}\end{array}$ \\
\hline 0 & 3.0847 & 6.0730 & 22.0120 & 46.4928 \\
5 & 1.4193 & 4.4004 & 16.2008 & 41.4922 \\
10 & 0.7989 & 3.5168 & 7.1783 & 31.7813 \\
15 & 0.3832 & 2.2954 & 4.0118 & 23.8724 \\
20 & 0.1671 & 1.7097 & 0.7946 & 16.6187 \\
\hline
\end{tabular}


It can be seen from Table 5 that as the proportion of straw ash increased, the flexural and compressive strength of cement mortar at $7 \mathrm{~d}$ and $28 \mathrm{~d}$ both showed a decreasing trend. Wherein, for the test pieces on $28 \mathrm{~d}$, the flexural strength decreased more dramatically than the compressive strength, for example, when the straw ash proportion was $5 \%$, compared with the standard test piece of $28 \mathrm{~d}$, the flexural strength decreased by $28 \%$, and the compressive strength decreased by $11 \%$; when the straw ash proportion was $10 \%$, compared with the standard test

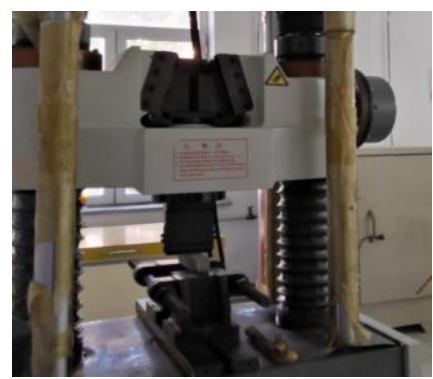

Figure 6. Flexure-resistance experiment

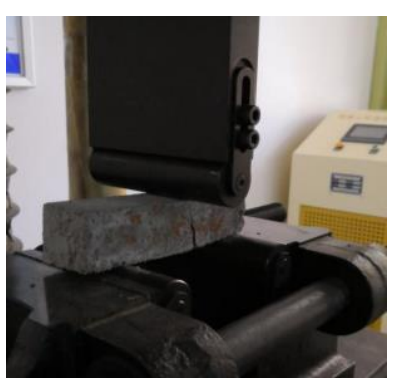

Figure 7. Flexural damage status of the test piece

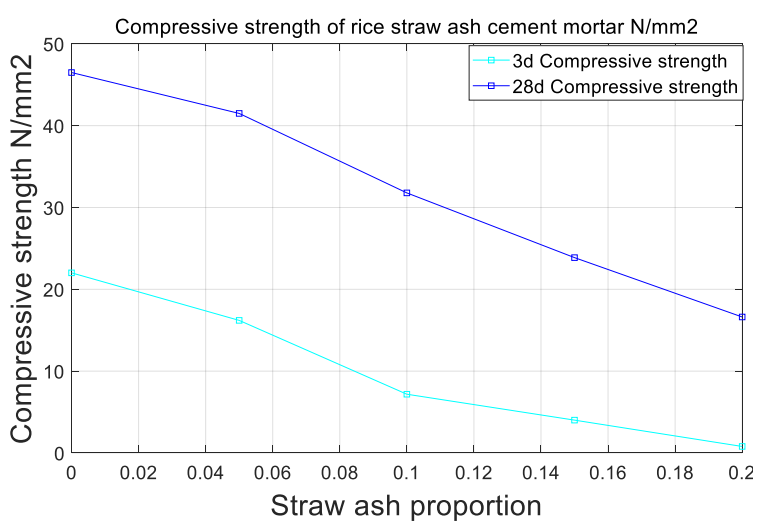

piece of $28 \mathrm{~d}$, the flexural strength decreased by $42 \%$, and the compressive strength decreased by $32 \%$; when the straw ash proportion was $20 \%$, compared with the standard test piece of $28 \mathrm{~d}$, the flexural strength decreased by $72 \%$, and the compressive strength decreased by $64 \%$. The flexural and compressive properties of the test piece ware shown in the Figures 6-9. The law of strength variation of test pieces was shown in the Figure 10.

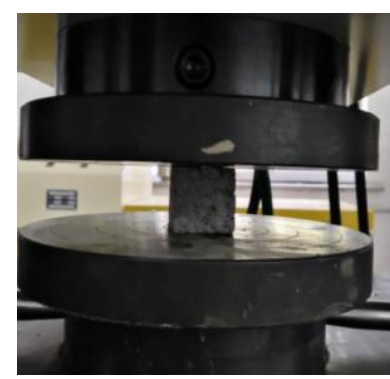

Figure 8. Compressionresistance experiment

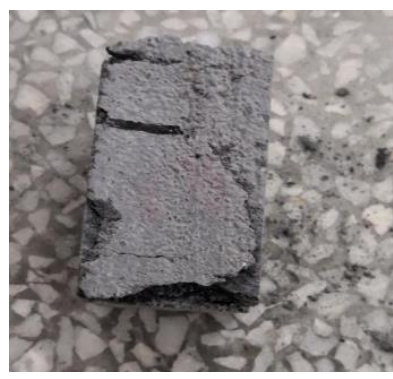

Figure 9. Compressive damage status of the test piece

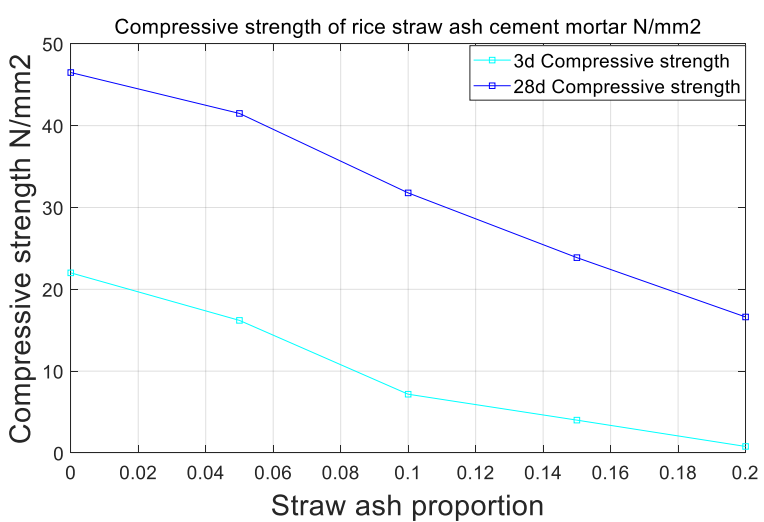

Figure 10. Strength of the test pieces

For the cement mortar, its flexural strength is lower than compressive strength, therefore the proportion of straw ash has a greater influence on the flexural strength than on the compressive strength. When the proportion of straw ash reached $20 \%$, the flexural strength and compressive strength of $28 \mathrm{~d}$ decreased greatly, reaching $72 \%$ and $64 \%$, respectively. In terms of the influence on curing age, by comparing the flexural strength and compressive strength of $3 \mathrm{~d}$ and $28 \mathrm{~d}$, it's found that the strength of straw ash cement mortar test pieces grew slowly during the curing cycle. After analysis we can know that, first, the straw ash has good fineness, large specific surface area, relatively large contact area with water and cement mortar; the rice straw ash contains a certain amount of $\mathrm{SiO}_{2}$, which has certain hydration activity and can accelerate the hydration reaction, although the activity has certain limitations, it can still play a certain role to improve the strength of the cement mortar; Second, when the proportion of straw ash is larger, the strength of the cement mortar decreases greatly, this is because there is a lot of cellulose and sugar in the plant straw, and during the curing of cement mortar test pieces, the straw sugar is easily precipitated in the closed environment and adsorbed on the surface of cement hydrate to inhibit the condensation of cement, causing retardation, thereby influencing the strength of the cement mortar.

\section{ESTABLISHMENT OF STRENGTH EQUATION OF STRAW ASH CEMENT MORTAR TEST PIECES}

Flexural and compressive strength equations of straw ash cement mortar.

The influence of rice straw ash proportion on the flexural strength of cement mortar was studied [17-20], and a mathematical calculation model was established and fitted by MATLAB curve fitting tool to obtain the fitting formulas (1) and (2). According to the experimental data, the curves of the equations were generated as shown in Figures 11 and 12. It can be seen from the figures that the curves formed by fitting had a better goodness of fit, and the correlation coefficient $\mathrm{R}^{2}$ was greater than 0.99 , indicating that the cement mortar strength and the straw ash proportion were well correlated. From the figures we can see that the flexural strength and compressive strength of straw ash concrete decreased with the increase of straw ash proportion. Flexural strength equation (1) and Compressive strength equation (2):

$p 1=53.01 \times x^{2}-32.27 \times x+6.03$

$p 2=3577 \times x^{3}-1150 \times x^{2}-62.38 \times x+46.6$ 
where: $p 1$-flexural strength, $\mathrm{N} / \mathrm{mm}^{2}$; p2-compressive strength, $\mathrm{N} / \mathrm{mm}^{2}$; $x$-straw ash proportion, $\%$.

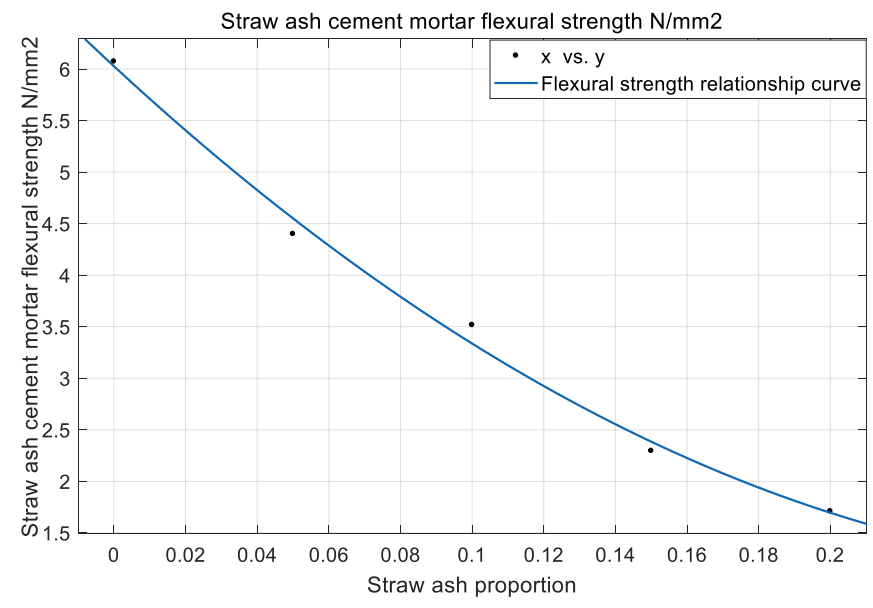

Figure 11. Flexural strength of straw ash cement mortar

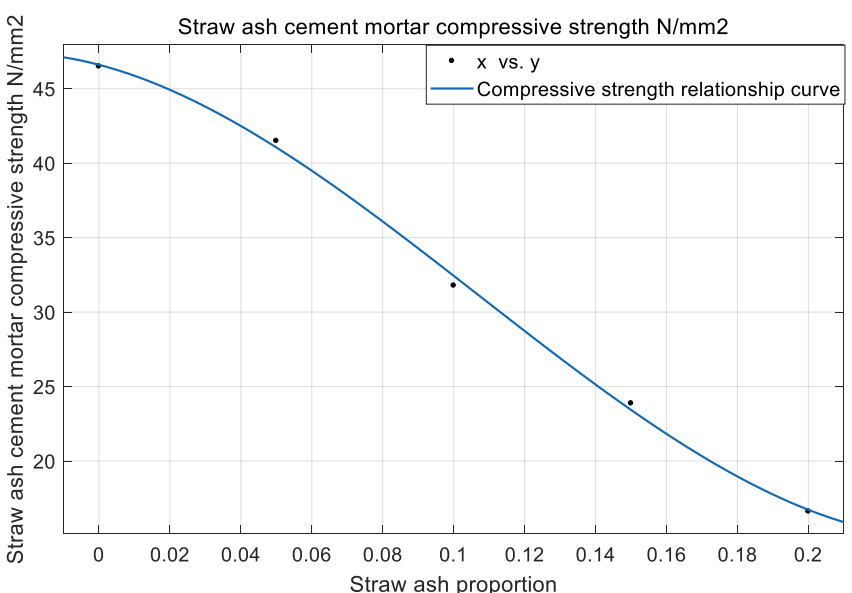

Figure 12. Compressive strength of straw ash cement mortar

The fitted strength formulas can be applied to the calculation of the strength of rice straw ash cement mortar to provide a basis for calculating the strength of cement mortar.

\section{CONCLUSION}

(1) By studying the ash formation rate of rice straw, it is found that at the same calcination temperature, the ash formation rate of rice straw decreases with the increase of calcination time; and under the same calcination time, the ash formation rate decreases with the increase of calcination temperature;

(2) By analyzing the water absorption rate of straw ash cement mortar, it is found that when the straw ash proportion increased from zero to $5 \%$, the water absorption rate increased by $17.84 \%$, the water absorption capacity of the straw ash cement mortar test pieces had been improved to some extent; when the straw ash proportion was between $5 \%$ and $15 \%$, the water absorption capacity increased slowly; when the straw ash proportion was $20 \%$, the water absorption capacity increased significantly, the optimum proportion is $10 \%$ in project;

(3) As the proportion of straw ash increased, the $3 \mathrm{~d}$ and $28 \mathrm{~d}$ flexural strength and compressive strength of cement mortar both showed a decreasing trend. Wherein, the $28 \mathrm{~d}$ flexural strength of the test pieces decreased more dramatically than the compressive strength. By fitting the experimental data of straw ash cement mortar, this paper proposed the flexural and compressive strength formulas of the straw ash cement mortar, which provided a basis for the calculation of the strength of the straw ash cement mortar

(4) Adding a proper proportion of rice straw ash in cement mortar can not only reduce the air pollution caused by incineration of rice straw in agricultural production, but also reduce the amount of cement, which is very important for the increasingly serious environmental pollution nowadays.

\section{ACKNOWLEDGEMENT}

This paper is supported by Academic Innovation Team of Chinese Academy of Tropical Agricultural Sciences (Project Number:19CXTD-31); National Tropical Fruit Germplasm Resource Nursery Platform, Zhanjiang, 524000; Heilongjiang Bayi Agricultural University Support Program for San Heng San Zong (Project Number: TDJH201803).

\section{REFERENCES}

[1] Han LJ, Yan QJ, Liu XY, Hu JY. (2002). Straw resources and their utilization in China. Transactions of the Chinese Society of Agricultural Engineering (Transactions of the CSAE) 18(3): 87-91. https://doi.org/10.3321/j.issn:1002-6819.2002.03.022

[2] Bricik H, Akz F, Berktay II, Tulgar AN. (1999). Study of pozzolanic properties of wheat straw ash. Cement and Concrete Research 29: 637-643. https://doi.org/10.1016/S0008-8846(98)00249-X

[3] Le Y, Li RS. (2006). Study on combustion characteristics of biomass. Energy Engineering (4): 30-33. https://doi.org/10.3969/j.issn.1004-3950.2006.04.008

[4] Zhang Q, Li YZ, Liu BH, Xu ZS. (2017). Mechanical properties and strength prediction of straw ash concrete. Transactions of the Chinese Society of Agricultural Engineering (Transactions of the CSAE) 33(2): 259-265. https://doi.org/10.11975/j.issn.1002-6819.2017.02.036

[5] Li CF, Su YW, Chen GP, Wang F. (2013). Study on properties of straw fiber reinforced concrete. Concrete 10 : 30-37. 3550.2013.10.008

[6] Ouyang D, Chen K. (2003). Microstructure and chemical activity of rice husk ash incinerated at low temperature. Journal of the Chinese Ceramic Society 31(11): 1121$1124 . \quad$ https://doi.org/10.3321/j.issn:04545648.2003.11.020

[7] Ministry of Housing and Urban-Rural Development of the People's Republic of China. (2011). Regulations for Mix Proportion Design of Ordinary Concrete (JGJ552011). Beijing: China Architecture\& Building Press 2535.

[8] Ministry of Housing and Urban-Rural Development of the People's Republic of China (2002). Standard for Test Method of Mechanical Properties on Ordinary Concrete (GB/T 50081-2002). Beijing: China Architecture\& Building Press 15-20.

[9] Deng L, Zhang T, Liu YH. (2010). Effect of washing on fuel properties and combustion characteristics of biomass. Journal of Engineering Thermophysics 31: 1239-1242. 
[10] Yan CW, Jia JQ, Zhang J. (2012). Experimental study of ratio between splitting tensile strength and compressive strength for steel fiber reinforce ultra high strength concrete. Journal of Dalian University of Technology (2): 233-238.

[11] Xiao JZ, Xu XD, Fan YH. (2013). Shrinkage and creep of recycled aggregate concrete and their prediction by Ann method. Journal of Building Materials 16(5): 752757. 9629.2013.05.003

[12] Wang JR. (2017). Application of extreme learning machine based on gray relational analysis in prediction of concrete compressive strength. Cement Engineering (3): 19-22. https://doi.org/10.13697/j.cnki.321449/tu.2017.03.006

[13] Plekhanova TA, Keriene J, Gailius A. (2006). Structural, physical and mechanical properties of modified woodmagnesia composite. Construction \& Building Materials 21: $1833-1838$ https://doi.org/10.1016/j.conbuildmat.2006.06.029

[14] Fan H, Sheng L. (2011). Experimental studies on performance of cement-based straw fiber material. Journal of Anhui Agricultural University 38(4): 643-646. https://doi.org/CNKI:34-1162/S.20110624.1621.007

[15] Nabil M, Al-Akhras, BA. (2002). Effect of wheat straw ash on mechanical properties of autoclaved mortar. Cement and Concrete Research 32: 859-863. https://doi.org/10.1016/S0008-8846(02)00716-0
[16] Zhang WJ, Liu BH. (2014). Experimental study on the hemp stalk's effect on the properties of lightweight aggregate concrete. Technological Development of Enterprise 33(1): 19-20. https://doi.org/10.3969/j.issn.1006-8937.2014.01.007

[17] Zhang Q, Liu BH, Liu QL. (2014). Effect of rape straw ash and silica fume admixture on concrete performance. Journal of Hunan Agricultural University (Natural Sciences) 40(3): $\quad 334-336$. https://doi.org/10.13331/j.cnki.jhau.2014.03.022

[18] Chang QW, Li QC, Liu CW. (2010). Effect of early maintenance on compressive strength of concrete. Architectural Design Management (1): 66-68. https://doi.org/10.3969/j.issn.1673-1093.2010.01.026

[19] Liu QL, Liu BH. (2013). Influence of Ashing conditions on the ash characteristics of rape straw. Journal of Hunan Agricultural University (Natural Sciences) (1): 107-110. https://doi.org/10.3724/SP.J.1238.2013.00107

[20] Huang W, Liu BH, Qi Z, Yi DH, Deng L. (2016). Erosion resistance on the sulfate for the rape straw doped ash concretes. Journal of Hunan Agricultural University (Natural Sciences) 42(2): 222-224. https://doi.org/10.13331/j.cnki.jhau.2016.02.022

[21] Yao XW, Xu KL. (2016). Effect of Ashing conditions on physicochemical properties of rice husk ash \& straw ash. Proceedings of the CSEE 3: 1633-1642. https://doi.org/10.13334/j.0258-8013.pcsee.2016.06.019 